\title{
An Exploration of Entrepreneurial Learning from Entrepreneuring Perspective: An entrepreneur's Experience Narrative
}

\author{
Min-Li Yang \\ Department of Business Administration \\ National Kaohsiung University of Science and Technology \\ Kaohsiung,Taiwan \\ minly@nkust.edu.tw
}

\author{
Chi-Ming Chung* \\ Department of Electronic Engineering (Business \\ Administration) \\ National Kaohsiung University of Science and Technology \\ Kaohsiung,Taiwan \\ 1101405118@nkust.edu.tw
}

\author{
Ching-Fang Lee \\ Department of International Trade \\ Shih Chien University \\ Kaohsiung,Taiwan \\ cflee@g2.usc.edu.tw
}

\begin{abstract}
The paradigm of research on entrepreneurialism has shifted from focusing on economic and entrepreneurship frameworks to the dynamic processes of lifelong entrepreneurial development, which has broadened the scope of research topics in the field of entrepreneurialism. To elucidate the process of entrepreneurial learning, this study adopted an action perspective to clarify the totality of entrepreneurial processes through the narrative of an entrepreneur named Ly. Through analyzing the diverse characteristics of entrepreneurial processes, this study identified the following three crucial implications: (a) entrepreneurial abilities and resources for entrepreneurs can be created from scratch; (b) the development of entrepreneurial abilities and acquisition of resources occurs through bottom-up processes; (c) entrepreneurial opportunities are derived through recognizing and understanding industry trends.
\end{abstract}

Keywords-Entrepreneuring perspective; Entrepreneurial learning; Narrative inquiry

\section{INTRODUCTION}

In this study, entrepreneurship was explored through an action perspective rather than a behavioral perspective to emphasize the totality of entrepreneurial processes. The diverse characteristics of such processes are affirmed through the narratives of entrepreneurs according to the actions they take when specific events occur. Understanding the daily life experiences of entrepreneurs is critical in studying entrepreneurship, and this perspective on entrepreneurship has extended conventional research in this field. From the entrepreneuring perspective, entrepreneurship is a type of action development occurring during processes. Therefore, entrepreneurial learning involves investigating the learning processes that entrepreneurs undergo in their life. It focuses not only on successful entrepreneurship, but also on how entrepreneurs interpret their past and future experiences.

\section{LITERATURE REVIEW}

\section{A. Changes in the Models of Entrepreneurial Studies}

The concept of entrepreneurship was first discussed by the economist Cantillon in the early eighteenth century. As more economists explored this concept, it became a mainstream topic in contemporary entrepreneurial research based on economics. Because entrepreneurship has led to the accumulation of wealth and development of social systems, entrepreneurial research has garnered increasing attention, and the range of topics in this field has continued to expand [1]. In addition to focusing on entrepreneurs, mainstream entrepreneurial studies have investigated topics such as innovation, opportunity identification, and business startups. Such studies have contributed to the rise of entrepreneurial research, with entrepreneurial research topics and perspectives becoming increasingly diverse over time.

\section{B. Entrepreneuring Perspective in Entrepreneurial Studies}

As mentioned in the introduction, recent entrepreneurial studies have shifted their focuses from the models based on economics and successful entrepreneurship to the new entrepreneurial research model based on dynamic processes by numerous scholars such as Sarasvathy [2,3],.Gartner, Carter and Hills [4], Cope [5,6], Cope and Watts [7] and Steyaert and Katz [8]. These scholars have adopted the new perspectives based on process theory as well as the processes of organizing; numerous crucial research topics have been formulated by focusing on the dynamic processes involved in lifetime entrepreneurial development [9]. McKeown [10] describes entrepreneurial learning is a complex and dynamic process. He demonstrates three theoretical perspectives on entrepreneurial learning. The first perspective is cognitive based that learning is essentially an intellectual endeavor. Second perspective of 
entrepreneurial learning is learning by doing. A third perspective of entrepreneurial learning is located within a specific community and everyday practice.

Steyaert [11].used the term "entrepreneuring," which is the verb form of the noun entrepreneurship, to describe this paradigm shift; thus, the term emphasizes the complex dynamics of entrepreneurship, enabling researchers to shift their focus from asking "why" questions to more practical "what" and "how" questions.

\section{Entrepreneurial Learning Through an Entrepreneuring Perspective}

The entrepreneurial actions addressed by Sarasvathy [2] and Gartner, Carter and Hills [4] are based on the organizing processes entrepreneurs derive from their past experiences and future vision. These studies were the first to investigate dynamic entrepreneuring on the basis of interactions between entrepreneurs and social living spaces.

\section{Analyzing the Entrepreneurial Learning Processes Through the Narratives of Entrepreneurs}

Entrepreneuring processes should be investigated through the narratives of entrepreneurs. Narrative inquiry involves analyzing stories from the perspective of resolving research questions. Stories contain contexts and scenarios that directly showcase the experience and practices of entrepreneurs and thus benefit other entrepreneurs more substantially when applied in entrepreneurial learning [12]. Entrepreneurial learning is facilitated through subjective education models, and its effectiveness varies with the skills of educators and the understanding and application abilities of learners. Additionally, entrepreneurial experience is typically passed down from learner to learner. Therefore, the effectiveness of entrepreneurial learning requires further examination. However, the entrepreneurial knowledge and experience in entrepreneurial stories are inarguably first-hand knowledge that can clarify the nature of entrepreneurial learning.

\section{METHODOLOGY}

\section{A. Narrative Inquiry and Entrepreneurial Story Analysis}

1) Scenarios as the Keys to Paraphrasing Narratives: Temporospatial scenarios are critical to investigating the entrepreneurial narratives because they reveal the temporality of events and phenomena.

2) Stories as Knowing Devices: Unlike case studies that incorporate stories as illustrative devices, studies that involve narrative inquiry apply stories as knowing devices. In other words, narrative inquiry requires understanding and knowing entrepreneurs through retelling their experiences as a story (storification). Case studies involve applying the surface information of stories as analytical elements and employing story content to verify and describe theories. Conversely, narrative inquiry requires analyzing narratives as research questions. Instead of focusing on the accuracy of story content, narrative inquiry focuses on why, how, and in what situation narrators use their narratives.
3) Theories as an Aid for Reading and Interpretation: In narrative inquiry, the theoretical backgrounds of researchers are effectively deconstruction frameworks for analyzing and interpreting narratives. In other words, theories provide a reading model through which researchers can identify meaningful experiences and narratives from texts. Furthermore, narrative data can be used to empirically support, challenge, or revise extant theories. In summary, theories are temporally assistive analysis tools that primarily enable researchers to observe and understand narratives in multiple dimensions, thus acting as a gateway to interpreting narratives and thereby establishing new insights [13].

\section{B. Data Collection and Sources}

1) Study site: This study investigated Hair Beauty Company $\mathrm{X}$, the headquarters of which are located in Kaohsiung City, Taiwan, with 17 chain stores in Taiwan, approximately 300 employees, a NT\$20 million in capital, and an annual turnover of approximately NT\$100 million. The interviewee of this study was the chief executive officer Ly of Company $\mathrm{X}$, who acquired controlling ownership of the company and transformed it into the leading hair beauty salon chain in Southern Taiwan through her persistent exploration and commitment.

2) Data collection and sources: The source of the interview data in this study was the narratives of Ly on her entrepreneur experience and processes. The interview was focused on investigating the psychological processes of Ly in her entrepreneurship. Each interview record was transcribed and verified by Ly to ensure the accuracy of the data. The interview recording was 5 hours in length, the transcript of which was 80 pages long.

\section{Data Management and Analysis}

The narrative inquiry involved four processes: transcription, storification, dialogical reasoning, and theoretical grounding. Through these processes, the data were organized into "thick descriptions" and inquiry findings. The research data were organized and analyzed through two primary phases: converting the narrative materials into field texts, and converting the field texts into research texts [14].

1) Data organization: converting the narrative material to field texts: Narrative materials are established through narrating specific lived experiences, and the implications embedded within the materials are typically fragmented, discontinuous, and omissive. Therefore, the story of Ly had to be transcribed, organized, and subsequently converted into field texts through discussions with Ly. The story plots were added, supplemented, and organized to bring out the ambiguous implications and improve the integrity of the story. Through Ly's participation in the transcription process, the researchers were able to provide cues for her to clarify ambiguous details regarding the background and context of the events she was involved in, and the stories were developed and new details were introduced through association [15]. 
2) Data analysis: converting the field texts to research texts: The narrative elements addressed by Pentland [16]were adopted as the primary analytical structure for the research texts. According to Pentland, a narrative contains the following five key elements: events, focal act(or)s, voice/perspectives, frame of reference and related contextual content. These five narrative elements were applied in analyzing the narrative of Ly to enable generalizing the implications of her entrepreneurial story. The interview data were interpreted through these elements.

\section{STORY ANALYSIS}

\section{A. Story One: Sudden Opportunity}

Regarding the beginning stage of her entrepreneurship, Ly stated with her eyebrows lowered. Ly worked to retain her employees and communicate with stakeholders (e.g., suppliers, property owners, and cooperating schools in the work-study program). At that time, Ly encountered problems daily. However, she supported her exhausted body with her entrepreneurial spirit. Instead of simply waiting for the problems to disappear, she actively requested help from stakeholders to stabilize the situation of Company X, which was achieved through her persistent efforts.

\section{B. Story Two: Managing Without Guidance}

According to her own work experience in several chain stores, Ly indicated that the relationships with the stores and commercial area around the salon were the basic source of customers for the salon. This revealed the local characteristics of the salon. For example, the performance of the chain stores in front of Sha Le Night Club and $\mathrm{Hu}$ Deal $\mathrm{Ku}$ Hotel is exceptional. The number of customers from such specific entertainment establishments in this area indicates the high spending power and population density of commercial areas. Trust plays a critical role in hair beauty businesses. A person's hairstyle is associated with his or her reputation, particularly form women; entrusting one's hairstyle design to a designer requires considerable understanding between both parties.

\section{Story Three: Inspiration Through Learning by Doing}

When Ly restarted Company X, her primary goal was to expand her business. Therefore, she seized every opportunity to attract new customers. She did not know how effective this approach would be, and her motivation was simple. Her intention was to expand the company's customer base through offering free haircuts, thereby creating opportunities to interact with customers and build their trust. Thus, the company could acquire loyal customers and generate profits. Ly indicated that the workload of her designers was considerable when the work volume increased. Subsequently, the cooperation between the salon and the insurance company lasted only for approximately 3 months. During this period, Ly also learned some techniques for attracting customers from the insurance company. From the moment she voiced her proposal to the day the cooperation ended, her only motivation was to expand the company's customer base. However, through word-of-mouth by the insurance company, the salon's customer base continued to increase. This was beyond Ly's expectation.

\section{Story Four: Cooperation and Affirmation from the Government}

Through Ly's persistent management style, Company X's profits gradually stabilized, and new chain stores were opened. Ly mentioned that when the Kaohsiung Women's Prison was established in 1995, the Agency of Corrections, Ministry of Justice aimed to help female prisoners to acquire job skills and appropriate life philosophies so that they could live independently when they were released from prison. Therefore, the agency selected hair beauty companies to open job skill classes for female prisoners.

\section{DISCUSSION}

We were genuinely interested in the entrepreneurial learning processes of Ly and the creation process of her entrepreneurial knowledge. If the knowledge was created through learning, then where and how did Ly acquire the knowledge with only a vocational high school education level?

\section{A. Making Do}

As revealed in Ly's early stage of entrepreneurship, she solved the problems she encountered through patchwork. When encountered with a problem, she searched among various solutions and identified the optimal one through a series of compromises, thereby learning and accumulating knowledge and experience as she managed the company. We analyzed that the entrepreneurial learning process of Ly, which proceeded without guidance, and found that it was not a self-evident paradigmatic learning process, but a process of knowing in practice [17]. Ly developed her own learning approach through her lived experiences, and her proactive personality enabled her to continually accumulate practical experience in business management. Although Ly never received formal paradigmatic instruction, she was able to accumulate entrepreneurial knowledge through a grassroots learning process to solve the problems she encountered.

\section{B. Bottom-Up Management Style}

Because Company $\mathrm{X}$ had failed in the past, Ly was particularly cautious in managing the new business unit. However, because she lacked entrepreneurial experience, she faced numerous problems in her entrepreneurial processes. From a human resource perspective, Ly indicated that in this industry, one would be forced to close without having relevant human resources. Therefore, developing and maintaining human resources was a focal point in managing a company in this industry.

\section{Creating New Opportunities}

The entrepreneurial opportunity for Ly arrived unexpectedly. After the employees of each store collectively left, company $\mathrm{X}$ faced the crisis of bankruptcy. The founder asked Ly whether willing to undertake company X. Ly thought that the brand of company $\mathrm{X}$ still has certain market. If she choose to leave, she may not be successful to restart her 
career. Therefore, she decided to become the new owner of Company X. As long as the market and customers still existed, with the existent resources, the company had a greater chance of becoming successful again. To Ly, this entrepreneurial opportunity was created from nothing. Furthermore, because Ly had profoundly invested in and managed this industry in the past, she was in a position to immediately derive the required resources through her human relations skills and selfconfidence. Thus, she was motivated and cherished the opportunity she had.

\section{CONCLUSION AND MANAGERIAL IMPLICATIONS}

This study maintained that daily life situations inspired Ly's problem-solving ability. This ability was created through accumulating experience over the years. She internalized daily life practices and experiences into unique field knowledge and applied it in the newly established organization. Through a series of negotiations and adjustments, this knowledge was ultimately reflected in her conduct as a manager, which enabled her to stabilize and develop the new company. Therefore, her learning processes did not involve conventional principles; rather, they were derived from her unique experiences as an entrepreneur. Her experiences may then exemplify that establishing a communication platform for entrepreneurs would be conducive to sharing and learning from the unique entrepreneurial experience of other entrepreneurs [11]

In summary, when entrepreneurial behaviors are considered as a type of practice that challenges personal experience, the problems and difficulties encountered by entrepreneurs are typically unfathomable. This study revealed that without acquiring the entrepreneurial abilities from conventional entrepreneurial learning mechanisms, Ly was successful in her entrepreneurship through developmental selflearning. Therefore, entrepreneurial learning can be attained through accumulating personal experience and internalizing resources. Through their investment and commitment in their industries, entrepreneurs can enhance showcasing their entrepreneurial spirits and the practices of their life.

\section{REFERENCES}

[1] S. Shane and S. Venkataraman, "The promise of entrepreneurship as a field of research,” Acad. Manag. Rev. vol. 25(1), pp. 217-226, 2000.

[2] S.D. Sarasvathy, "Causation and effectuation: toward a theoretical shift from economic inevitability to entrepreneurial contingency," Acad. Manag. Rev. vol. 26, pp. 243-263, 2001.

[3] S.D. Sarasvathy, "Entrepreneurship as a science of the artificial," J. Econ. Psychol, vol. 24, pp. 203-220, 2003.

[4] W.B. Gartner, N.M. Carter, and G.E. Hills, "The language of opportunity," in C. Steyaert, and D.Hjorth (eds), New Movements in Entrepreneurship.Cheltenham: Edward Elgar, pp. 103-124, 2003.

[5] J. Cope, "Researching entrepreneurship through phenomenological inquiry," Int Small Bus. J. vol. 23(2), pp. 163-189, 2005 a.

[6] J. Cope, "Toward a dynamic learning perspective of entrepreneurship," Entrep. Theory Pract. vol. 29(4), pp. 373-97, 2005 b.

[7] J. Cope and G. Watts, "Learning by doing: An exploration of experience, critical incidents and reflection in entrepreneurial learning," Int. J. Entrep. Behav. R. vol. 6, pp. 104-24, 2000.

[8] C. Steyaert and J. Katz, "Reclaiming the space of entrepreneurship in society: geographical, discursive and social dimensions," Entrep. Region. Dev. vol.16, pp. 179-196, 2004.

[9] D. Hjorth and B. Johannisson, "Building new roads for entrepreneurship research to travel by: On the work of William B. Gartner," Small Bus. Econ. vol. 31(4), pp. 341-350, 2008.

[10] I. McKeown, "Entrepreneurial learning in small firm management teams," In D. Rae and C.L. Wang (Eds), Entrepreneurial learning (pp. 25-58). Routledge, 2015.

[11] C. Steyaert, "Entrepreneuring as a conceptual attractor? A review of process theories in 20 years of entrepreneurship studies," Entrep. Region. Dev. vol. 19(11), pp. 453-477, 2007.

[12] S.J. Li, "Breakthrough and frontiers: portrayal of people in entrepreneurship studies," J. Entrep. R. vol. 5, pp. 91-104, 2010.

[13] W.B. Gartner and C.B. Brush, "Entrepreneurship as organizing: Emergence,newness and transformation," In T. Habbershop, and M. Rice (Eds), Praeger Perspectives on Entrepreneurship, CT: Praeger Publishers, 2007, pp. 1-20.

[14] S.J. Li, "The sensemaking process of the entrepreneur: A narrative approach,” J. Entrep. R. vol. 6, pp.11-82, 2011.

[15] D.H. Tsai, C.C. Shih, and S.J. Li, “ Narrating an entrepreneurial story: Awareness, learning, and reinterpretation," Organ.Manag. vol. 3, pp. $67-$ 91, 2010.

[16] B.T. Pentland, "Building process theory with narrative: From description to explanation,” Acad. Manag. R. vol. 24(4), pp. 711-724, 1999.

[17] W.J. Orlikowski, "Knowing in practice: Enacting a collective capability in distributed organizing," Organ. Sci. vol. 13(3), pp. 249-273, 2002. 